\title{
TANGGUNG JAWAB PELAKU USAHA PANGAN SIAP SAJI DIHUBUNGKAN DENGAN ASAS KEAMANAN DAN KESELAMATAN KONSUMEN
}

\author{
Wiwin Widiyaningsih \\ Notwin85@yahoo.com \\ DOI: https://doi.org/10.29313/sh.v16i2.5357
}

\begin{abstract}
ABSTRAK
Pangan siap saji merupakan usaha kuliner yang cukup berkembang tetapi dalam peredarannya belum memenuhi standar keamanan pangan akibatnya banyak konsumen dirugikan dan menuntut tanggung jawab pelaku usaha. Tujuan penelitian adalah (1) untuk mengetahui tanggung jawab hukum pelaku usaha pangan siap saji. (2) untuk mengetahui upaya penegakan hukum terhadap pelaku usaha pangan siap saji. Metode Penelitian menggunakan pendekatan yuridis normatif, jenis data sekunder, teknik pengumpulan data menggunakan studi kepustakaan dengan teknik analisis kualitatif. Hasil penelitian menunjukkan (1) Pelaku usaha yang memperdagangkan pangan siap saji tidak memenuhi standar keamanan pangan dan menimbulkan kerugian konsumen dibebani tanggung jawab langsung, (2) Upaya penegakan hukum untuk menyelesaikan sengketa akibat mengkonsumsi pangan siap saji dapat menempuh 2 (dua) jalur yaitu (a) Melalui gugatan perdata ke pengadilan (litigasi) (b) Melalui musyawarah untuk mufakat di luar pengadilan (non-litigasi).
\end{abstract}

Kata Kunci: Tanggung Jawab, Keamanan dan Keselamatan, Pangan Siap Saji

\section{ABSTRACT}

Ready-to-eat food is a fairly developed culinary effort, but in its circulation it has not met food safety standards as a result, many consumers are harmed and demand the responsibility of business actors. The research objectives are (1) to find out the legal responsibilities of ready-to-eat business actors. (2) to find out about law enforcement efforts against ready-to-eat business actors. The research method uses a normative juridical approach, the type of secondary data, data collection techniques using library studies with qualitative analysis techniques. The results of the study show (1) Business actors that trade in ready-to-eat food do not meet food safety standards and cause consumer losses burdened with direct responsibility. (2) Law enforcement efforts to resolve disputes due to consuming ready-to-eat food which cause consumer losses according to positive law can take 2 (two) paths, namely (a) Through civil lawsuits to court (litigation). This rule provides space for consumers to sue through the Dis trict Court. By considering several aspects, namely the process is long and rigid, expensive, unresponsive to the wishes of the parties, decisions are unfair and the ability of judges is general. (b) Through deliberation to reach consensus outside the court (non- litigation) 
Keywords: Responsibility, Security and Safety, Food Ready to Serve.

\section{A. PENDAHULUAN}

\section{Latar Belakang Masalah}

Pangan adalah kebutuhan pokok manusia yang tidak dapat ditinggalkan maupun digantikan dengan yang lain di dalam kehidupannya sehari-hari, hal itu dikarenakan tanpa adanya makanan atau minuman yang dikonsumsi oleh manusia maka mereka tidak akan dapat aktif dan produktif di dalam menjalankan aktivitasnya. Oleh karena itu produk makanan dan minuman yang memiliki mutu bagus dan layak untuk dikonsumsi sesuai dengan standar mutu keamanan pangan sangat dibutuhkan oleh konsumen untuk kelangsungan hidup mereka. Dengan demikian keamanan pangan merupakan salah satu faktor yang penting dan wajib diperhatikan oleh konsumen dalam memilih produk makanan yang hendak dikonsumsi, agar tidak membahayakan keselamatan dan kesehatan hidupnya sendiri. ${ }^{1}$

Berkaitan dengan keamanan pangan siap saji di Indonesia masih belum dapat dikatakan memenuhi standar keamanan pangan dikarenakan permasalahan yang berkaitan dengan keamanan pangan siap saji akhir-akhir ini masih banyak terjadi, sebagai contoh adalah masalah keracunan makanan, biskuit beracun, mie instan beracun, susu beracun, roti beracun. Permasalahan yang berkaitan dengan keamanan pangan itu sendiri adalah produk-produk pangan siap saji yang sudah tidak layak konsumsi, misalnya karena sudah kadaluwarsa, ataupun produk makanan yang dikonsumsi yang di dalamnya mengandung zat-zat kimia yang jika dikonsumsi oleh manusia akan membahayakan kesehatan bahkan keselamatan jiwanya. ${ }^{2}$ Ditambah dengan adanya perilaku pelaku usaha yang berbuat curang dalam menjalankan usahanya, ${ }^{3}$ bahan pengawet yang mereka gunakan pada produk yang dipasarkan adalah bahan pengawet yang dilarang oleh pemerintah. ${ }^{4}$

\footnotetext{
${ }^{1}$ Aman Wirakarkusumah, Perindungan Konsumen Produk Pangan, Jakarta, 1987, hlm. 12.

${ }^{2}$ Edi Setiadi dan Rena Yulia, Hukum Pidana Ekonomi, Graha Ilmu, Yogyakarta, 2010, hlm 183.

${ }^{3}$ Teguh Sulistia, Perlindungan Hukum dan Pemberdayaan Pengusaha Kecil dalam Ekonomi Pasar Bebas, Jurnal Hukum Bisnis Vol 27, No 1, 2008, hlm. 17.

${ }^{4}$ Firman Tarumantara, Kriminalisasi Klausula Baku, Jurnal Ilmu Hukum Litigasi, Vol 10, No 3, 2009, hlm 283 .
} 
Fakta di lapangan ada sejumlah pelaku industri pangan siap saji yang memproduksi dan mengedarkan pangan siap saji menggunakan bahan tambahan pangan yang melebihi batas maksimum yang menyebabkan konsumen mengalami keracunan. Seperti yang tercatat oleh Sistem Informasi Keracunan (Siker) Badan Pengawas Obat dan Makanan (BPOM). di bawah ini: ${ }^{5}$

Menurut BPOM beberapa pelaku usaha yang menggunakan jenis BTP yang dilarang oleh Permenkes No 033 Tahun 2012 Tentang Bahan Tambahan Pangan. Beberapa bahan pengawet yang biasa digunakan pelaku usaha pangan antara lain: ${ }^{6}$

1. Asam borat dan senyawanya (boric acid) yang pada umumnya digunakan untuk anti septik pada lantai atau bahan baku untuk las karbit, bila konsumen mengkonsumsinya beresiko terkena ginjal atau kanker;

2. Formalin (formaldehiyde) yang biasanya digunakan untuk mengawetkan mayat, kloramfenikol yang sering digunakan oleh industri makanan udang segar, namun biasanya para produsen menggunakan melebihi dosis agar udang terlihat tetap segar.

3. Pewarna tekstil yang dapat menyebabkan kanker atau gagal ginjal. Bahan pengawet makanan yang digunakan oleh produsen tersebut mengandung senyawa kimia yang berbahaya bagi orang yang mengkonsumsinya.

Bahan-bahan tersebut telah dilarang oleh Permenkes No 033 Tahun 2012 Tentang Bahan Tambahan Pangan yang dilampirkan pada lampiran II namun dipasaran bahan ini banyak beredar dan dimiliki oleh para pelaku usaha pangan siap saji karena memiliki fungsi mampu mempengaruhi bentuk dan warna makanan menjadi lebih segar. ${ }^{7}$ Menuntut pertanggungjawaban pelaku usaha di bidang pangan cepat saji yang terbukti melakukan produksi dan perdagangan pangan yang membahayakan konsumen merupakan suatu keniscayaan untuk menciptakan keadilan, karena selama ini sudah cukup banyak peredaran pangan yang tidak sesuai dengan standardisasi keamanan yang dipersyaratkan oleh undang-undang.

Persoalan keamanan pangan memerlukan solusi yang cepat agar memberikan perlindungan keamanan dan keselamatan konsumen. Mengingat produksi pangan siap saji saat ini cukup banyak dan peredarannya di tengah

\footnotetext{
${ }^{5}$ Data rekapitulasi tahunan Badan Pengawas Obat dan Makanan (BPOM) September 2018.

${ }^{6}$ Fransiska Zakaria. Komponen Kimia Berbahaya. Materi Pelatihan Singkat Keamanan Pangan, Standar dan Peraturan Pangan. PAU Pangan dan Gizi IPB, 1994, hlm. 32.

${ }^{7}$ Fransiska Zakaria, Komponen Kimia Berbahaya, Jakarta, 1992, hlm 23.
} 
masyarakat sangat cepat. Peredaran pangan cepat saji ke tangan konsumen harus diikuti dengan tanggung jawab yang jelas dan pasti baik dalam wilayah hukum administrasi, perdata maupun pidana.

\section{Identifikasi Masalah}

Artikel ini akan membahas Bagaimana tanggung jawab hukum pelaku usaha pangan siap saji yang menimbulkan kerugian konsumen dihubungkan dengan asas keamanan dan keselamatan, dan bagaimana upaya penegakan hukum terhadap pelaku usaha pangan siap saji menurut hukum positif untuk menyelesaikan sengketa yang memberikan perlindungan bagi konsumen.

\section{Metode Penelitian}

Metode penelitian dalam penulisan ini menggunakan pendekatan yuridis normatif karena penulis mengkaji peraturan perundang-undangan yang mengatur pangan siap saji serta asas keamanan dan keselamatan konsumen dengan menggunakan data sekunder yang dikumpulkan melalui teknik studi kepustakaan dan dianalisis secara kualitatif.

\section{B. PEMBAHASAN}

\section{a. Tanggung Jawab Pelaku Usaha Pangan Siap Saji yang Menimbulkan Kerugian Konsumen Dihubungkan dengan Asas \\ Keamanan dan Keselamatan}

Menuntut tanggung jawab hukum pelaku usaha pangan siap saji didasarkan pada asas keamanan dan keselamatan yang dianut oleh Undang-Undang No 8 Tahun 1999 Tentang Perlindungan Konsumen. Dalam Pasal 2 dijelaskan bahwa" "Perlindungan konsumen berasaskan manfaat, keadilan, keseimbangan, keamanan dan keselamatan konsumen, serta kepastian hukum.

Ketentuan mengenai tanggung jawab pelaku usaha termasuk di dalamnya pelaku usaha pangan siap saji diatur dalam Pasal 19 Undang-Undang No 8 Tahun 1999Tentang Perlindungan Konsumen menyatakan bahwa:

(1) Pelaku usaha bertanggung jawab memberikan ganti rugi atas kerusakan, pencemaran, dan atau kerugian konsumen akibat mengkonsumsi barang dan atau jasa yang dihasilkan atau diperdagangkan. 
(2) Ganti rugi sebagaimana dimaksud pada ayat (1) dapat berupa pengembalian uang atau penggantian barang dan/atau jasa yang sejenis atau setara nilainya, atau perawatan kesehatan dan/atau pemberian santunan yang sesuai dengan ketentuan peraturan perundang-undangan yang berlaku.

(3) Pemberian ganti rugi dilaksanakan dalam tenggang waktu 7 (tujuh) hari setelah tanggal transaksi.

(4) Pemberian ganti rugi sebagaimana dimaksud pada ayat (1) dan ayat (2) tidak menghapuskan kemungkinan adanya tuntutan pidana berdasarkan pembuktian lebih lanjut mengenai adanya unsur kesalahan.

(5) Ketentuan sebagaimana dimaksud pada ayat (1) dan ayat (2) tidak berlaku apabila pelaku usaha dapat membuktikan bahwa kesalahan tersebut merupakan kesalahan konsumen.

Berdasarkan ketentuan ini maka kewajiban pelaku usaha pangan siap saji untuk bertanggung jawab secara teoritis-konseptual ditentukan sebagai berikut: ${ }^{8}$

1. Pelaku usaha bertanggung jawab secara langsung ketika terjadi kerusakan, pencemaran dan kerugian konsumen akibat mengkonsumsi pangan yang diperdagangkan.

2. Bentuk ganti rugi yang diterima konsumen pangan berupa:

a. Penggantian barang/jasa yang sejenis atau setara nilainya

b. Perawatan kesehatan

c. Pemberian santunan

3. Waktu pengaduan ditentukan secara limitatif (7 hari setelah transaksi).

4. Pembayaran ganti rugi tidak menutup kemungkinan bagi jaksa untuk melakukan penuntutan berdasarkan unsur kesalahan.

5. Pelaku usaha dapat dibebaskan dari tanggung jawab apabila dapat membuktikan bahwa kerugian karena kesalahan konsumen.

Bertolak dari ketentuan Pasal 19 Undang-Undang No 8 Tahun 1999 Tentang Perlindungan Konsumen menunjukkan bahwa pelaku usaha pangan siap saji dibebani tanggung jawab langsung seketika terjadi kerugian pada konsumen. Kerugian konsumen pangan siap saji dapat diidentifikasi berupa kerugian atas

${ }^{8}$ Adrian Sutedi, Tanggung Jawab Produk, Ghalia Indonesia, Bogor, 2008, hlm. 29. 
kesehatan sehingga ganti rugi yang diberikan adalah biaya perawatan karena konsumen mengalami gangguan kesehatan.

Merujuk Pasal 19 Undang-Undang Perlindungan Konsumen secara yuridis hukum telah mengatur bahwa setiap pelaku usaha pangan yang memperdagangkan makanan siap saji ketika tidak mematuhi peraturan tentang pangan yang aman ketika konsumen merasa dirugikan karena mengkonsumsi pangan tersebut maka pada saat itu pula pelaku usaha langsung bertanggung jawab memberikan ganti rugi. Tanggung jawab langsung diartikan sebagai bentuk penggantian kerugian seketika sesaat terjadinya perbuatan yang melanggar hak orang lain. Jadi tanpa harus menunggu prose s pengadilan, bentuk tanggung jawab ini terjadi karena ada klaim konsumen kepada pelaku usaha atas kualitas pangan yang merugikan konsumen. Tanggung jawab ini menuntut respon secara langsung dari pelaku usaha pangan untuk mendengar dan memberikan apa yang menjadi tuntutan pasien.

Meskipun secara hukum pelaku usaha pangan dibebani tanggung jawab langsung dalam kenyataan sering ditemukan banyak konsumen yang menderita kerugian seperti gangguan kesehatan akibat mengkonsumsi pangan siap saji pelaku usaha tidak bertanggung jawab secara langsung meskipun konsumen sudah menyampaikan keluhan dan tuntutan. Terutama pangan siap saji yang dijual oleh pedagang kaki lima (PKL) banyak yang tidak memenuhi standar keamanan pangan mulai dari bahan maupun alat yang digunakan, sehingga ketika terjadi kerugian, konsumen harus menanggung kerugian sendiri. ${ }^{9}$

Secara faktual masih banyak pelaku usaha pangan siap saji yang tidak melaksanakan tanggung jawab langsung. Bila diidentifikasi ada beberapa sebab pelaksanaan tanggung jawab langsung tidak dilaksanakan, yaitu:

1. Konsumen tidak mengetahui bahwa mereka berhak atas kenyamanan, keamanan, dan keselamatan dalam mengkonsumsi barang;

\footnotetext{
${ }^{9}$ Balai Pengawasan Obat dan Makanan, Perijinan BPOM, Artikel Desember 2007, hlm 28.
} 
2. Konsumen tidak mengetahui bahwa mereka berhak atas informasi yang benar, jelas, dan jujur mengenai kondisi dan jaminan barang;

3. Pendapat dan keluhan konsumen atas barang yang digunakan tidak mendapat respon positif dari pelaku usaha;

4. Tidak mengetahui hak atas advokasi, perlindungan, dan upaya penyelesaian sengketa perlindungan konsumen secara patut;

5. Berhak untuk mendapatkan kompensasi, ganti rugi dan/atau penggantian, apabila barang yang diterima tidak sesuai dengan perjanjian atau tidak sebagaimana mestinya;

6. Konsumen tidak menghendaki sengketa yang memakan tenaga, waktu dan biaya yang mahal.

Praktik ini bila dihubungkan dengan asas keamanan dan keselamatan konsumen tidak menunjukkan kesesuaian karena menurut prinsip ini seyogyanya setiap produk yang diedarkan harus memenuhi standar keamanan pangan sehingga tidak membahayakan keselamatan konsumen yang mengkonsumsi. Dalam Penjelasan Undang-Undang Perlindungan Konsumen ditegaskan bahwa asas keamanan dan keselamatan konsumen dimaksudkan untuk memberikan jaminan atas keamanan dan keselamatan kepada konsumen dalam penggunaan, pemakaian dan pemanfaatan barang dan/atau jasa yang dikonsumsi atau digunakan.

Pencantuman asas keamanan dan keselamatan dalam Undang-Undang Perlindungan konsumen merupakan bukti bahwa ketentuan yang mengatur di bidang hukum perlindungan konsumen menjamin setiap produk yang diperdagangkan pelaku usaha aman untuk dikonsumsi. Jika kemudian ditemukan produk yang menyalahi asas keamanan dan keselamatan maka pelaku usaha harus langsung bertanggung jawab. Kewajiban tanggung jawab gugur bila pelaku usaha mampu membuktikan bahwa kerugian konsumen bukan karena kesalahannya. Keamanan dan keselamatan menjadi salah satu tujuan pemerintah untuk melindungi konsumen dari produk pangan yang membahayakan kesehatan. Oleh karena itu, terbuka peluang konsumen untuk menuntut tanggungjawab pelaku usaha. ${ }^{10}$

\footnotetext{
${ }^{10}$ Az Nasution, Konsumen dan Hukum, Pustaka Sinar Harapan, Jakarta, 1995, hlm 32.
} 


\section{b. Upaya Penegakan Hukum terhadap Korporasi dalam Tindak Pidana Lingkungan Hidup di Wilayah Provinsi Jawa Barat Dihubungkan dengan Usaha Pemulihan Lingkungan Hidup}

Upaya penegakan hukum yang dapat dilakukan untuk memberikan perlindungan kepada konsumen pangan siap saji dapat dilakukan dengan merujuk pada berbagai ketentuan yang ada dalam Undang-Undang No 8 Tahun 1999 tentang Perlindungan Konsumen yang mengatur proses penegakan hukum yang muncul karena ada sengketa konsumen. Analisis mengenai upaya penegakan hukum dalam rangka menyelesaikan kerugian dalam sengketa konsumen terdapat 2 (dua) langkah yang dapat ditempuh oleh konsumen yang mengalami kerugian akibat mengkonsumsi pangan siap saji, antara lain.

\section{Melalui Gugatan Perdata Pengadilan Negeri (Litigasi)}

Konsumen yang mengalami kerugian akibat produk pangan siap saji dapat menuntut keadilan dengan menggunakan jalur pengadilan dengan menuntut secara perdata melalui gugatan ke pengadilan negeri. Langkah ini telah diatur dalam Pasal 45 ayat (1) Undang-Undang No 8 Tahun 1999 Tentang Perlindungan Konsumen.

"Setiap konsumen yang dirugikan dapat menggugat pelaku usaha melalui lembaga yang bertugas menyelesaikan sengketa antara konsumen dan pelaku usaha atau melalui peradilan yang berada di lingkungan peradilan umum”.

Ketentuan mengenai hukum acara yang berlaku apabila konsumen menempuh jalur perdata melalui pengadilan adalah ketentuan yang ada dalam hukum acara perdata (Kuhperdata). Dalam Pasal 46 Undang-undang No 8 Tahun 1999 Tentang Perlindungan Konsumen disebutkan bahwa:

(1) Gugatan atas pelanggaran pelaku usaha dapat dilakukan oleh:
a. seorang konsumen yang dirugikan atau ahli waris yang bersangkutan;
b. kelompok konsumen yang mempunyai kepentingan yang sama;
c. lembaga perlindungan konsumen swadaya masyarakat yang memenuhi syarat, yaitu berbentuk badan hukum atau yayasan, yang dalam anggaran dasarnya menyebutkan dengan tegas bahwa


tujuan didirikannya organisasi tersebut adalah untuk kepentingan perlindungan konsumen dan telah melaksanakan kegiatan sesuai dengan anggaran dasarnya; pemerintah dan/atau instansi terkait apabila barang dan/atau jasa yang dikonsumsi atau dimanfaatkan mengakibatkan kerugian materi yang besar dan/atau korban yang tidak sedikit.

(2) Gugatan yang diajukan oleh sekelompok konsumen, lembaga perlindungan konsumen swadaya masyarakat atau pemerintah sebagaimana dimaksud pada ayat (1) huruf b, huruf c, atau huruf d diajukan kepada peradilan umum.

Secara yuridis konsumen telah memiliki dasar hukum yang kuat untuk menggugat pelaku usaha secara perdata. Meskipun demikian, penggunaan gugatan perdata dalam praktik belum dilaksanakan secara optimal karena keterbatasan pemahaman konsumen terhadap produk yang dikonsumsinya, ditambah Undangundang No 8 Tahun 1999 Tentang Perlindungan Konsumen tidak memberikan kekhususan dalam gugatan konsumen secara perdata. Gugatan dilakukan melalui proses perdata biasa, artinya gugatan perdata terhadap pelaku usaha harus menempuh proses beracara biasa yang penuh formalitas. Dengan demikian, dapat diperkirakan bahwa untuk sampai pada putusan pengadilan memperoleh kekuatan hukum tetap bisa memakan waktu lama dan belum tentu menang. Undang-Undang sama sekali tidak memberikan prioritas pemeriksaan perkara gugatan atas kerugian konsumen. Di samping itu, pelaku usaha (tergugat) bisa menggugat balik dan kemungkinan justru pelaku usaha yang menang dan konsumen yang harus membayar tuntutan pelaku usaha. ${ }^{11}$

Untuk menggugat pelaku usaha yang merugikan konsumen melalui pengadilan dengan hukum acara perdata biasa memang memiliki risiko selain biaya dan memakan waktu yang cukup lama konsumen juga tidak mendapatkan kepastian mengenai penggantian besaran kerugian, karena belum tentu gugatannya

\footnotetext{
${ }^{11}$ Ari Purwandi, Hukum Perdata pada Perlindungan Konsumen, Juridika, No 1 dan 9, Tahun VII, 1992, hlm. 128.
} 
dimenangkan oleh majelis hakim. Meskipun demikian apabila konsumen atau kuasanya memiliki bukti- bukti lengkap yang menunjukkan bahwa telah terjadi pelanggaran terhadap hak-hak konsumen, maka jalur gugatan perdata dapat menjadi pilihan untuk menuntut pelaku secara perdata.

Selain konsumen memiliki bukti yang cukup, pelaku usaha juga diwajibkan untuk membuktikan gugatan konsumen, karena dalam Pasal 28 Undang-Undang No 8 Tahun 1999 Tentang Perlindungan Konsumen menegaskan bahwa:

"Pembuktian terhadap ada tidaknya unsur kesalahan dalam gugatan ganti rugi sebagaimana dimaksud dalam Pasal 19, Pasal 22, dan Pasal 23 merupakan beban dan tanggungjawab pelaku usaha".

Ketentuan ini menunjukkan bahwa Undang-Undang Perlindungan Konsumen menganut prinsip pembuktian terbalik dalam perkara penyelesaian sengketa konsumen. Artinya pelaku usaha dibebani kewajiban untuk membuktikan bahwa kerugian yang diderita oleh konsumen bukan akibat dari kesalahannya. Aturan ini bertujuan untuk memberikan perlindungan kepada konsumen karena tidak memiliki pengetahuan yang memadai mengenai komposisi, bahan dan pengawet yang digunakan dalam pengolahan pangan yang ditawarkan oleh pelaku usaha sehingga Undang-undang mewajibkan pelaku usaha yang wajib untuk membuktikan.

\section{Penyelesaian Secara Musyawarah di Luar Pengadilan (Non Litigasi)}

Upaya untuk mewujudkan perlindungan konsumen pangan siap saji melalui selain menempuh jalur litigasi juga dapat ditempuh jalur non litigasi atau musyawarah. Apabila para pihak bersepakat sengketa yang terjadi antara mereka diselesaikan secara cepat, efisien dan murah maka jalur non litigasi (musyawarah) dapat menjadi pilihan. Penyelesaian dengan musyawarah ini diatur dalam Pasal 45 ayat (2) Undang-Undang No 8 Tahun 1999 Tentang Perlindungan Konsumen yang menegaskan bahwa:

"Penyelesaian sengketa konsumen dapat ditempuh melalui pengadilan atau di luar pengadilan berdasarkan pilihan sukarela para pihak yang bersengketa" 
Aturan hukum di atas telah memberikan pilihan kepada para pihak yang bersengketa untuk memilih apakah ingin menyelesaikan melalui jalur litigasi atau non litigasi. Pilihan menyelesaikan sengketa melalui non litigasi seperti mediasi atau alternatif penyelesaian sengketa lainnya dapat ditempuh karena memiliki beberapa keuntungan, yaitu: ${ }^{12}$

1. Penyelesaian dilaksanakan secara damai/kekeluargaan.

2. Proses non litigasi relatif lebih cepat tanpa memakan waktu yang lama dan biaya ringan.

3. Melalui musyawarah para pihak dapat menyelesaikan persoalan secara arif dan bijakasana dengan memperhatikan kepentingan konsumen dan pelaku usaha.

Musyawarah merupakan proses pembahasan suatu persoalan dengan maksud mencapai keputusan bersama. Tujuannya adalah untuk mencapai kesepakatan (mufakat) setelah melakukan proses pembahasan persoalan secara bersama. Musyawarah mufakat adalah cara untuk menghindari proses peradilan yang akan memakan waktu lama. Melalui musyawarah mufakat diharapkan kedua belah pihak yang bersengketa dapat menyelesaikan persoalan dan mendapat jalan tengah.

Konsumen yang menjadi korban pangan siap saji yang tercemar dapat mengajukan upaya musyawarah dengan meminta kepada pelaku usaha untuk memberikan ganti rugi yang diderita oleh konsumen akibat kesalahan pelaku usaha dalam memperdagangkan produknya.

Dalam proses penyelesaian ganti rugi konsumen yang menjadi korban BPSK memiliki peran penting untuk membantu konsumen dalam memperoleh hak-haknya. Musyawarah yang berlangsung harus dimediasi oleh BPSK, karena lembaga tersebut dibentuk untuk bertugas menyelesaikan sengketa konsumen. Sebagaimana diatur dalam Pasal 52 bahwa:

Tugas dan wewenang Badan Penyelesaian Sengketa Konsumen meliputi:

a. melaksanakan penanganan dan penyelesaian sengketa konsumen, dengan cara melalui mediasi atau arbitrase atau konsiliasi;

b. memberikan konsultasi perlindungan konsumen;

${ }^{12}$ Happy Susanto, Hak-hak Konsumen Jika Dirugikan, Transmedia Pustaka, Jakarta, 2008, hlm. 18. 
c. melakukan pengawasan terhadap pencantuman klausula baku;

d. melaporkan kepada penyidik umum apabila terjadi pelanggaran ketentuan dalam Undang-undang ini;

e. menerima pengaduan baik tertulis maupun tidak tertulis, dari konsumen tentang

f. terjadinya pelanggaran terhadap perlindungan konsumen;

g. melakukan penelitian dan pemeriksaan sengketa perlindungan konsumen;

h. memanggil pelaku usaha yang diduga telah melakukan pelanggaran terhadap perlindungan konsumen;

i. memanggil dan menghadirkan saksi, saksi ahli dan/atau setiap orang yang dianggap mengetahui pelanggaran terhadap Undang undang ini;

j. meminta bantuan penyidik untuk menghadirkan pelaku usaha, saksi, saksi ahli, atau setiap orang sebagaimana dimaksud pada huruf g dan huruf $h$, yang tidak bersedia memenuhi panggilan badan penyelesaian sengketa konsumen;

k. mendapatkan, meneliti dan/atau menilai surat, dokumen, atau alat bukti lain guna penyelidikan dan/atau pemeriksaan;

1. memutuskan dan menetapkan ada atau tidak adanya kerugian di pihak konsumen;

m. memberitahukan putusan kepada pelaku usaha yang melakukan pelanggaran terhadap perlindungan konsumen;

n. menjatuhkan sanksi administratif kepada pelaku usaha yang melanggar ketentuan Undang undang ini.

Keberhasilan proses musyawarah dalam kasus pangan beracun atau tercemar sangat bergantung pada kerjasama dan kesepakatan para pihak untuk menyelesaikan secara kekeluargaan. Dalam proses musyawarah menuntut adanya kehadiran fisik dari para pihak baik pelaku maupun konsumen sangat urgen untuk dilaksanakan karena tanpa kehadiran salah satu pihak sulit untuk mempertemukan kehendak para pihak. Dalam musyawarah tersebut konsumen sebagai korban dapat mengutarakan kemauannya supaya pelaku membayar ganti rugi yang telah diderita konsumen.

Aspek penting dalam sengketa konsumen adalah bagaimana kerugian yang diderita oleh konsumen dapat dipulihkan oleh pelaku sebagai kompensasi atas perbuatan yang dilakukannya. Pembayaran sejumlah ganti rugi dilakukan apabila telah tercapai sebuah kesepakatan antara pelaku dengan konsumen mengenai besarannya. Perlu dicatat bahwa meskipun pelaku telah membayar ganti rugi kepada 
konsumen akibat pangan siap saji yang menimbulkan kerugian tidak serta merta pelaku dapat terbebas dari tanggung jawab pidana. Walaupun pelaku sudah mengganti rugi, tanggung jawab bila konsumen menuntut secara pidana maka ganti rugi itu tidak menghilangkan tanggung jawab pidananya. Sebagaimana diatur dalam Pasal 45 ayat (3) Undang- Undang Perlindungan Konsumen yang mengatur bahwa:

"Penyelesaian sengketa di luar pengadilan sebagaimana dimaksud pada ayat (2) tidak menghilangkan tanggung jawab pidana sebagaimana diatur dalam UndangUndang".

Ketentuan ini menunjukkan bahwa upaya penyelesaian sengketa konsumen melalui jalur non litigasi bertujuan untuk mengembalikan kerugian konsumen akibat kesalahan pelaku usaha bukan untuk membebaskan dari tanggung jawab pidana.

Pangan siap saji merupakan salah satu aktivitas perekonomian yang sangat cepat perkembangannya dan menunjang pertumbuhan ekonomi nasional. Perdagangan pangan siap saji masuk dalam kategori aktivitas perekonomian mikro yang dijalankan oleh para pedagang di berbagai pusat perbelanjaan (modern dan konvensional). ${ }^{13}$

Penegakan hukum dalam menuntut tanggung jawab pelaku usaha pangan siap saji dianggap sebagai usaha memberikan perlindungan terhadap konsumen yang mengalami kerugian akibat mengkonsumsi pangan yang diedarkan dan bertujuan untuk memberikan pencegahan agar orang lain tidak melakukan perbuatan yang sama.

Upaya penegakan hukum menurut Soerjono Soekanto dalam bidang apapun selalu dipengaruhi oleh 5 (lima) faktor yaitu Undang-Undang yang baik, penegak hukum yang berintegritas, sarana dan prasarana yang memadai, perilaku masyarakat dan kebudayaan. Bertolak dari pemikiran Soerjono Soekanto menganalisis penegakan hukum penyelesaian sengketa konsumen pangan siap saji secara yuridis formal telah didukung oleh Undang-Undang yang baik (UndangUndang Perlindungan Konsumen dan Undang-Undang Pangan) yang mengatur

\footnotetext{
${ }^{13}$ Ahmadi Miru dan Sotarman Yodo, Hukum Perlindungan Konsumen, PT Raja Grafindo Persada, Jakarta, 2011, hlm. 42.
} 
penyelesaian sengketa dan tata cara menuntut tanggung jawab pelaku usaha pangan yang tidak mematuhi peraturan perundang-undangan. Meskipun demikian belum menjamin pelaksanaan penegakan hukum karena pelaku usaha belum memiliki budaya ketaatan hukum yang baik, terbukti dengan banyaknya laporan kasus pangan yang mengandung bahan berbahaya bagi kesehatan masyarakat. Umumnya pelaku usaha hanya mengutamakan keuntungan ekonomi tanpa mempertimbangkan kesehatan pasien. ${ }^{14}$

Penegakan hukum untuk menyelesaikan sengketa yang memberikan perlindungan konsumen harus ditunjang dengan instrumen-instrumen sebagaimana dikemukakan Soerjono Soekanto. Jadi selain membentuk regulasi di bidang pangan perlu dibudayakan pembinaan bagi para pelaku usaha untuk menaati peraturan terkait keamanan pangan secara terpadu. Aturan di bidang keamanan pangan pada hakikatnya bertujuan untuk memberikan perlindungan atas keamanan dan keselamatan konsumen/

\section{PENUTUP}

Pelaku usaha yang memperdagangkan pangan siap saji tidak memenuhi standar keamanan pangan dan menimbulkan kerugian konsumen dibebani tanggungjawab langsung sesuai Pasal 19 Undang-Undang No 8 Tahun 1999 Tentang Perlindungan Konsumen berupa pengembalian uang atau penggantian barang yang sejenis atau setara nilainya, atau perawatan kesehatan dan/atau pemberian santunan. Tanggung jawab pelaku usaha pangan diatur pula dalam Pasal 76 Undang-Undang No 18

Tahun 2012 Tentang Pangan dengan sanksi administrasi berupa denda, penghentian sementara kegiatan produksi dan peredaran, penarikan pangan dari peredaran, ganti rugi dan pencabutan izin. Meski demikian masih banyak pelaku usaha pangan siap saji tidak melaksanakan tanggung jawab langsung karena unsur ketaatan pelaku usaha masih rendah dan keterbatasan konsumen atas hak-haknya. Kondisi ini ${ }^{14}$ Ali Mansyur, Penrlindungan Hukum tentang Tanggung Gugat Produsen dalam
Perwujudan Perlindungan Konsumen, Genta Press, Yogyakarta, 2007, hlm. 18. 
tidak sesuai dengan asas keamanan dan keselamatan yang menuntut pelaku usaha untuk menjamin produk yang aman dan tidak membahayakan keselamatan konsumen.

Upaya penegakan hukum untuk menyelesaikan sengketa akibat mengkonsumsi pangan siap saji yang menimbulkan kerugian konsumen menurut hukum positif dapat menempuh 2 (dua) jalur yaitu:

1. Melalui gugatan perdata ke pengadilan (litigasi) berdasarkan Pasal 45 ayat (1) Undang-undang No 8 Tahun 1999 Tentang Perlindungan Konsumen. Aturan ini memberikan ruang bagi konsumen untuk menggugat melalui Pengadilan Negeri. Dengan mempertimbangkan beberapa aspek yaitu proses berjalan lama dan kaku, biaya mahal, tidak responsif terhadap keinginan para pihak, putusan tidak adil dan kemampuan hakim bersifat general.

2. Melalui musyawarah untuk mufakat di luar pengadilan (non-litigasi) yang diatur dalam Pasal 45 ayat (2) Undang-undang No 8 Tahun 1999 Tentang Perlindungan Konsumen. Dengan menggunakan alternatif penyelesaian sengketa dan meminta Badan Penyelesaian Sengketa Konsumen (BPSK) untuk mengadakan musyawarah untuk mencapai kesepakatan dengan mempertemukan para pihak. Model ini memiliki kelebihan karena diselesaikan secara damai/kekeluargaan, proses relatif cepat dan berorientasi memberikan perlindungan untuk memulihkan kerugian konsumen baik berupa pengembalian uang atau penggantian barang yang sejenis, perawatan kesehatan dan/atau pemberian santunan.

Untuk menanggulangi peredaran pangan siap saji yang tidak memenuhi kriteria pangan yang aman disarankan kepada:

1. Pemerintah dan pemerintah daerah untuk membina dan mengawasi pelaksanaan penerapan standar, dan kriteria Keamanan Pangan sesuai jenis dan skala usaha pangan untuk mencegah kemungkinan cemaran biologis, kimia, dan benda lain yang dapat mengganggu, merugikan, dan membahayakan kesehatan konsumen.

2. Pelaku usaha pangan untuk memperhatikan standar keamanan pangan supaya tidak membahayakan kesehatan konsumen dan bertanggung jawab 
Syiar Hukum Jurnal Ilmu Hukum | Volume 16 Nomor 2

secara langsung kepada konsumen ketika konsumen mengklaim mengalami kerugian akibat mengkonsumsi produk pangan siap saji. 


\section{DAFTAR ISI}

\section{A. Buku}

Adrian Sutedi, Tanggung Jawab Produk, Ghalia Indonesia, Bogor, 2008.

Ahmadi Miru dan Sotarman Yodo, Hukum Perlindungan Konsumen, PT Raja Grafindo Persada, Jakarta, 2011.

Ali Mansyur, Perlindungan Hukum tentang Tanggung Gugat Produsen dalam Perwujudan Perlindungan Konsumen, Genta Press, Yogyakarta, 2007.

Aman Wirakarkusumah, Perlindungan Konsumen Produk Pangan, Jakarta, 1987. Az Nasution, Konsumen dan Hukum, Pustaka Sinar Harapan, Jakarta, 1995.

Edi Setiadi dan Rena Yulia, Hukum Pidana Ekonomi, Graha Ilmu, Yogyakarta, 2010.

Fransiska Zakaria, Komponen Kimia Berbahaya, Jakarta, 1992.

Data rekapitulasi tahunan Badan Pengawas Obat dan Makanan (BPOM) September 2018

Fransiska Zakaria. Komponen Kimia Berbahaya. Materi Pelatihan Singkat Keamanan Pangan, Standar dan Peraturan Pangan. PAU Pangan dan Gizi IPB, 1994.

Happy Susanto, Hak-hak Konsumen Jika Dirugikan, Transmedia Pustaka, Jakarta, 2008

\section{B. Jurnal/Makalah}

Ari Purwandi, Hukum Perdata Pada Perlindungan Konsumen, Juridika, No 1 dan 9, Tahun VII, 1992.

Firman Tarumantara, Kriminalisasi Klausula Baku, Jurnal Ilmu Hukum Litigasi, Vol. 10, No 3, 2009

Balai Pengawasan Obat dan Makanan, Perijinan BPOM, Artikel Desember 2007 
Teguh Sulistia, Perlindungan Hukum dan Pemberdayaan Pengusaha Kecil dalam Ekonomi Pasar Bebas, Jurnal Hukum Bisnis, Vol 27, No 1, 2008

\section{Peraturan Perundang-undangan}

Undang-undang No 8 Tahun 1999 Tentang Perlindungan Konsumen

Undang-undang No 18 Tahun 2012 Tentang Pangan

Peraturan Menteri Kesehatan No 033 Tahun 2012 Tentang Bahan Tambahan Pangan

Peraturan Kepala Badan Pengawas Obat dan Makanan No 36 Tahun 2013

Tentang Batas Maksimum Penggunaan Bahan Tambahan Pangan Pengawet. 
Barda Nawawi Arief, Pembaruan Penegakan Hukum dengan Nilai-nilai Moral Religius, Makalah disampaikan pada Seminar Nasional Menembus Kebuntuan Legal Formal Menuju Pembangunan Hukum dengan Pendekatan Hukum Progresif, FH Undip 19 Desember 2009.

Barda Nawawi Arief, Korporasi Sebagai Subjek Hukum Pidana, Seminar Masyarakat Hukum Pidana dan Kriminologi (Mahupiki), Mei 2015.

I.S. Susanto, Tinjauan Kriminologis tentang Kejahatan Ekonomi, Makalah pada Penataran Hukum Pidana dan Kriminologi, UNDIP, Semarang 23-30 November 1998.

Saifuddin, Tindak Pidana Lingkungan Korporasi, Makalah disampaikan pada Simposium Hukum Pidana, Universitas Lambung Mangkurat, Banjarmasin, 2015.

\section{Peraturan Perundang-undangan}

Undang-Undang Dasar 1945

Undang-Undang No 32 Tahun 2009 Tentang Perlindungan dan Pengelolaan Lingkungan Hidup 